\title{
The Comparative Analysis of Micro-credit Model of Chinese Commercial Banks
}

\author{
Xin Gao \\ Marx Institute \\ Northeast Dianli University \\ Jilin, China 132012
}

\begin{abstract}
The development of the manufacturing industry in China is progressing at a slow rate due to the business finance practices utilized. In turn, some commercial banks have carried on a series of practices and search within this field. Q commercial bank implements the strategy of transition and gradually strengthens core competitiveness. This paper focuses on the analysis of the micro credit quality and loan proceeds. For example, $\mathbf{Q}$ commercial banks, compared to other commercial banks and their Micro-credit model, sum up the success of Micro-finance model, provide the feasible suggestions of the Micro-finance business for other commercial banks.
\end{abstract}

Keywords-Commercial Banks; miniature business; Micro-finance; Micro-credit model

\section{INTRODUCTION}

In recent years, $Q$ commercial banks have actively explored its market positioning, developing Micro credit business strategies, and, combined with the successful model of the cash credit, summed up a set of effective measures.

\section{THE ANALYSIS OF THE MicRo CREDIT QUALITY AND LOAN PROCEEDS OF THE COMMERCIAL BANKS}

In order to explain the difference between $\mathrm{Q}$ commercial banks and other commercial banks in the business, Shanghai Bank and China Merchants Bank (that are committed to miniature business financing) were chosen as the objects of the case analysis in this paper. Two aspects were examined: loan quality (bad - loan ratio, capital adequacy ratio) and loan proceeds (average annual return - on - assets)

\section{A. Comparative Analysis of Loan Quality}

\section{1) Non-performing loan comparison}

$\mathrm{Bad}$ - loan ratio is an essential tool to measure the loan quality of commercial banks. Not only does it directly reflect the quality of the loan, it also shows the risk of commercial banks to recover the loan ratio. The average NPL ratio comparison results of Q commercial bank, China Merchants Bank, and Shanghai bank of the China banking industry between 2007-2012 are shown in "Table 1".
TABLE I. AVERAGE NPL RATIO COMPARISON OF Q COMMERCIAL BANK, CHINA MERCHANTS BANK, SHANGHAI BANK AND CHINA B ANKING INDUSTRY FROM 2007 TO 2012

\begin{tabular}{|l|l|l|l|l|l|l|}
\hline Bank & 2007 & 2008 & 2009 & 2010 & 2011 & 2012 \\
\hline Q bank & 3.59 & 3.16 & 0.99 & 0.79 & 0.65 & 0.64 \\
\hline $\begin{array}{l}\text { China } \\
\text { Merchants Bank }\end{array}$ & 1.54 & 1.11 & 0.82 & 0.68 & 0.56 & 0.61 \\
\hline Shanghai Bank & 2.41 & 2.23 & 1.59 & 1.12 & 0.98 & 0.84 \\
\hline $\begin{array}{l}\text { China banking } \\
\text { industry } \\
\text { average }\end{array}$ & 6.2 & 2.42 & 1.58 & 1.14 & 1.77 & 1.56 \\
\hline
\end{tabular}

From "Table. 1" the annual financial statements for the collation of data, three banks non-performing loan rates are lower than the national average level of the banking industry. China Merchants Bank Non-performing loan rate has been at a considerably low level, being far below the national average level of the banking industry. For Q commercial banks, the ratio from $3.16 \%$ of 2008 rapidly drops to $0.99 \%$ in 2009 . In 2009, Q commercial banks provided cross regional microfinance business. The NPL ratio of miniature business has decreased significantly, reflecting the strong control ability of the loans and a high level of loan quality.

\section{2) Capital Adequacy Ratio Comparison}

Capital adequacy ratio mainly reflects the ability of resisting micro-credit risk of the commercial banks. The higher the capital adequacy ratio is, the stronger ability to lower micro-finance risk [1]. In 2007-2012, Q commercial banks, China Merchants Bank, Bank of Shanghai, the average capital adequacy ratio comparison result is shown in "Table. 2".

TABLE II. THE CAPITAL ADEQUACY RATIO COMPARISON OF Q COMMERCIAL BANK, CHINA MERCHANTS BANK, BANK OF SHANGHAI FROM 2007 TO 2012

\begin{tabular}{|l|l|l|l|l|l|l|}
\hline Banks & 2007 & 2008 & 2009 & 2010 & 2011 & 2012 \\
\hline Q banks & 8.58 & 10.72 & 13.12 & 11.57 & 13.70 & 13.13 \\
\hline $\begin{array}{l}\text { China } \\
\text { Merchant } \\
\text { s Bank }\end{array}$ & 10.4 & 11.34 & 10.45 & 11.47 & 11.53 & 12.14 \\
\hline $\begin{array}{l}\text { Shanghai } \\
\text { Bank }\end{array}$ & 11.27 & 11.27 & 10.29 & 10.70 & 11.75 & 13.17 \\
\hline
\end{tabular}

From the data in "Table. 2", we can see that the capital adequacy rate of $\mathrm{Q}$ commercial bank has been significantly 
improved since 2009, it indicate that adequate funding is the premise of the micro-credit operations, it provide feasibility for the micro-finance.

\section{3) Yields in Bank Loan Comparisons}

The loan price of Commercial bank is influenced by the cost of capital, operating cost, risk cost, expected yields and other factors. Commercial banks want to gain high yields of micro-credit income in order to minimize the risk [2-3]. Q Commercial Bank, China Merchants Bank and Shanghai bank loan yields from 2007-2012 comparison are shown in "Table. 3".

TABLE III. Q COMMERCIAL BANK, CHINA MERCHANTS BANK, BANK OF SHANGHAI, THE AVERAGE YIELDS IN B ANKS' LOAN COMPARISON FROM 2007 TO 2012

\begin{tabular}{|l|l|l|l|l|l|l|}
\hline Banks & 2007 & 2008 & 2009 & 2010 & 2011 & 2012 \\
\hline Q banks & 0.52 & 1.46 & 1.06 & 1.23 & 1.05 & 1.21 \\
\hline $\begin{array}{l}\text { China } \\
\text { Merchants Bank }\end{array}$ & 1.36 & 1.45 & 1.00 & 1.15 & 1.39 & 1.46 \\
\hline Shanghai Bank & 1.03 & 0.91 & 0.87 & 0.97 & 0.95 & 1.02 \\
\hline
\end{tabular}

In "Table. 3" can be seen that Yields in Q banks' loan continued to maintain in more than $1 \%$ since the beginning of 2008. The level of loan proceeds shows the Q Commercial bank micro-finance model can effectively solve the problems of miniature business loans.

\section{B. Micro-credit Model of Commercial Bank-Credit Objects}

Because of the attempting to make efforts on the credit object, the non-performing loan ratio of the commercial banks dropped below $1 \%$. The object of credit can be divided into four categories: farmers, individuals, small businesses, and miniature businesses. Farmers and miniature businesses loans have become new economic growth points. Considering the water resources condition, the four loan objects were chosen by Q commercial bank. The farmers' loans are the product of credit market for $\mathrm{Q}$ commercial banks. In the city, there are a large number of individual operators and miniature businesses, and the funding gap is even larger, Q commercial banks take the opportunity to establish its own market position.

Q commercial banks use risk identification and risk measurement evaluation when screening the credit objects, effectively avoid risk of micro-finance. The object was concentrated on the shopping district, the industrial park, high-quality small businesses, and the network industry; they have a higher credit rating; business growth increases rapidly. Risk identification and risk measurement ensure the quality of the credit object; they laid solid foundation for credit business to grow and provide risk control.

\section{Micro-credit Model of Commercial Bank-Credit Product}

\section{1) Group Lending}

In the collection of customer information, commercial banks pay higher cost. Micro-finance is even higher, but group lending solves the problem.

It can greatly reduce the customer information collection costs. By the way of group lending, many enterprises can jointly apply for a loan. Business loans will choose less risky enterprises as partners within this mechanism. It certain extent alleviated information asymmetry which the review and the actual information, reduce the cost of the inspection [4-5].

\section{2) Relationship Loan}

Group lending is primarily used for farmers loans. It is difficult to implement the group loans for miniature business. Unlikely the information shared by all the farmers, most enterprises will conceal their business information. Therefore, group loans do not apply to small and micro enterprise loan [6]. Q Commercial banks explored new credit products relationship loan for miniature business loans. Under the circumstances, commercial banks and enterprise finance establish long-term relations of cooperation, so as to manage the borrower's financial data and business conditions. According to the information available to determine the specific amount of loans, the key to relationship lending is that commercial banks must pay more attention to the dynamic information of the business. The difficulty is that collecting closed information may bring more burden to the bank. In order to solve the problem, commercial banking collects the information through the support of the correspondents (e.g. village committee members, rural grassroots members or party members). The local information officer has jurisdiction, and they conduct field visits to provide more accurate and comprehensive information (for example understanding of enterprise information, production status, reputation degree) to the commercial banks rather than others.[7].

\section{Micro-credit Model of Commercial Bank-Credit Management}

In the process of carrying out the micro credit business, commercial banks not only need to consider the loan risk, they must consider the realization of income which commensurate with income of traditional loans, too. Due to the small scale of microfinance fund and quantity transactions, commercial banks often need to cost more. Commercial banks have to continue to reduce the cost of the non- financial, which is the loan cost. Therefore, commercial banks internally establish special loan managing department. They make sure the loan transaction procedures are efficiently streamlined and reduce the approval process. The batch processing professional team can effectively reduce the transaction costs of microfinance.

The entire traditional loans lending process is quite the performance. Commercial banks simplify the process of the 
loan and repayment, by means of payment in cash, agent transfer, designated loan, and direct remittances to provide the multi-channel loan way for customers. This effectively reduces the loan time cost [8].

Traditional bank loan approvals often need a loan application, a credit rating, an investigation of legitimacy, and etc. Commercial bank micro-finance established an independent examination and approval mechanism along with three members of the group for examination and approval (in a "three approval, one vote veto" procedural format). This greatly simplifies the approval process and improves the efficiency of examination and approval. Traditional banks generally manage the loan after three months. Commercial banks did not identify a fixed management real - time to manage the loan, but according to the actual situation of small and micro enterprises. The approach is beneficial to commercial banks to keep abreast of business benefit, avoid missing the optimal clearance time, and effectively reduce the non-performing loan rate. Commercial banks risk the default in the process of microcredit business. Therefore, in order to avoid the default business, commercial banks established the sharing information system between the various branches. Loans and are recovered in a timely manner. Bad credit information is discovered and reported in a timely manner. As a result, there is an avoidance of customer default risk.

\section{CONCLUSION}

From three aspects (credit object, credit products, and credit management) the paper expounds on commercial banks, presents the innovation of micro-credit and the difference of loans from traditional bank. Comparison of non-performing loan ratio, capital adequacy ratio, and loan proceeds between Q commercial bank and Shanghai Bank, China Merchants Bank reflects the advantage and implementation effect of the micro-finance model.

\section{REFERENCES}

[1] Zhou Mengliang, Li Mingxian. The Mode land Mechanism of Big Commercial Banks Involving in Microfinance in the View of Inclusive Financial System [J].Reform.2011.04.

[2] Chen Cheng, Xu Zhichun. Study on the development path of disruptive innovation of commercial bank credit business based on Small and micro businesses [J]. Science \& Technology Progress and Policy, 2013.24.

[3] Li Chaoxin, Chen Yongbing. Analysis of micro credit risk control and insurance policy of commercial bank -- Based on the new concept of the main game [J].Wuhan Finance.2013.12.

[4] Tang Wei. Study on the problems of establishing rural microfinance system -- Based on the experience of the Rural Bank of Bangladesh [J]. World Agriculture. 2012.02.

[5] Zhou Chuangyang. The reasons and solutions of miniature business financing -- Based on the successful experience of the credit model in the rich bank [J]. China National Conditions and Strength.2012.05.

[6] Gu Haifeng. The research on the transmission and control mechanism of the banc assurance cooperation under the credit risk of commercial banks - Based on the analysis from the perspective of system science [J]. Studies of International Finance. 2013.02.
[7] Shi Changliang. A comparative analysis of improved entropy method based on the performance of commercial banks in China $[\mathrm{J}]$ Studies of regional Finance.2013.02. 